\title{
Students' Pronunciation Errors in English Silent Letters
}

\author{
Winda Pusfarani \\ English Education Study Program, Department of Language and Art \\ University of Bengkulu \\ windapusfarani@gmail.com \\ Mukhrizal \\ English Education Study Program, Department of Language and Art \\ University of Bengkulu \\ mukhrizal58@gmail.com \\ Hilda Puspita \\ English Education Study Program, Department of Language and Art \\ University of Bengkulu \\ puspitahilda@gmail.com \\ Corresponding email: windapusfarani@gmail.com
}

\begin{abstract}
The objective of this research was to find out the types of pronunciation errors are made by the seventh semester students of English education study program at Bengkulu University in the academic year 2020/2021. This research used a descriptive quantitative method. 94 students as the total population 30 students were chosen randomly as the samples. The instrument of the research were pronunciation test and interview. The test comprises 52 sentences which contain 13 silent letters i.e. " $k$, gh, th, g, p, l, t, s, w, n, b, h, d". Each letter appears 4 times in the test. The results of the research showed that the students made two types of errors namely pre-systematic errors and systematic errors. The pre-systematic errors occurred more frequently than the systematic errors. The highest errors made by the students were silent letters "g" (e.g. gnaw) and "b" (e.g. doubt) which total numbers of errors of each of them were 93 times (77\%). It could be concluded that the students faced high difficulties in pronouncing the silent letters which completely different from Indonesian phonetic system. It was recommended that the English lecturers should pay more attention to students' pronunciation and find more suitable method or technique of teaching it and students should study harder about the silent letters in English language.
\end{abstract}

Keywords: Error, Pronunciation, Silent Letter 


\section{Introduction}

Pronunciation is the way of someone pronounce or speak out the words that accepted or understood in a particular language. It is often being as a kind of skill to show that someone have superiority in mastering English. Gilakjani (2012) stated that pronunciation is an integral part of foreign language learning since it directly affects learners' communicative competence and performance. Some people judge English competence based on speaking in a good pronunciation ability rather than from any other language skills. Moreover, people are considered successful in the language if they can fluently pronounce their second and foreign language.

Nowadays, mastering English is significant since language is a means of communication and interaction among individuals. The development of process globalization and modernization brings people to live together in a global life in the world. It cannot be avoided in a worldwide society if someone needs to interact and communicate with different backgrounds, languages, and cultures. Thus, the international language function as the primary means used by English speaking people to interact with each other and build a relationship with their community.

Even though as quoted by Kenworthy (1987), the main goal of learning pronunciation is to be native-like. There are many problems with understanding English spoken at a natural speed by native speakers who speak with various accents. Non-native English also has issues in talking. The problems are dealing with phonetic and phonology understanding. Wherefore, every English learner has their own phonetic words dealing with their native languages such as Indonesian, Javanese, Sumatran, Sundanese, etc. English learners in every country, also often pronounce English differently from native because it depends on their accent. However, their pronounce still excepted and understood by others. As quoted by Brown (2000) that English pronunciation should be more realistically focus on transparent and comprehensible pronunciation. For instance, Singapore, Australia, India, 
Thailand, Japanese, Korean, etc. However, for English learners, their mother tongue influences them on how to perform English.

In the performance in speaking English, Indonesian phonotactic rules still carried. The English and Indonesian phonological systems are different in certain aspects. As quoted by Pallawa (2013), Indonesians have difficulty in pronouncing English words since there are many phonological rules in English which do not exist in Bahasa Indonesia. In English, words contain the letter [I] and $[p]$ in the final position, such as the scalp, pulp, and help. However, those clusters are situated in different Indonesian syllables, such as al-pa, pul-pen, and tel-pon. Therefore, Indonesians have difficulty pronouncing those letters and a tendency to spell those words by adding schwa [ə] between [I] and [p]. In this case, Indonesian speakers have a problem pronouncing English words regarding the limitation of Indonesian phonological rules. Other examples /ps/ in Indonesia and /ps/ in English, Psikologi, and Psychology. In Indonesia, this letter /ps/ pronounce at once. However,/ps/ in English, the [p] is silent, and only [s] is pronounced. This phenomenon can cause pronunciation errors for Indonesian students who perform English spoken language.

One thing that always happened in the errors of speaking English is silence in a letter. Silent letter defines as a letter which is not pronounced in a word, it is present in spelling but missed in pronunciation. According to Podhaizer (1998), stated that the silent letters are letters which are not sounded. Therefore, English learners, while faced with silent letter words, were often confused about the pronunciation. Even some students know the silent letter's rules, but when they perform it, they made some errors. Furthermore, some students do not learn the rules and the correct pronunciation of the words. Last, students often applied the correct rule but performed it inconsistently. Brown (2007) defines the error as a noticeable deviation from the adult grammar of native speaker, reflecting the interlanguage competence of the learners. As quoted by Taylor (1997), an error is an inevitable uncertainty that 
attends to all measurements. The word error carries different definitions from the word mistake or false. Error is related to the sense of anticipation.

It also happened in the English Education Study Program at the University of Bengkulu. However, Pronunciation demanded by English study program students. They should have good pronunciation. After all, they have to speak clearly in front of the students because they will become a teacher. Pronunciation as one matter of learning new languages plays an essential role in realizing the target language since it is the way of sounding those languages. Pronunciation has an important role in communicating with each other. If someone error in pronouncing a word, the listener will misinterpret it, lead to misunderstanding, and then create miscommunication.

The big numbers of pronunciation errors is proved on previous study which is done conducted in the same place as this research, the English Education Study Program at University of Bengkulu. The study that conducted by Styvant et al. (2019) the findings indicates that the English students have average predicate in pronouncing syllable words stress in the first and second syllable also low predicate in two stresses in a word. The study shows that the most students of the English education study program still mispronounce some English words especially in pronouncing syllable words stress.

Also, a study conducted in 2018 by Utama's research showed that the types of errors in pronouncing the silent letter were varied. The error was occurred because of the nature of the mother tongue. Then, in 2017 Salwa, the study results revealed that the students made errors in certain sounds, and the most frequent type of interlingual errors of pronunciation made by students was [ $\theta$ ] sound. Moreover, there is one study conducted in 2016 by Alqunayeer. The result of study showed that the most frequent errors occurred in the letter " $g$ ". Also, Ayumi (2018) found that the students' pronunciation that correctly silenced the silent letter was higher than incorrect.

In order to investigate the types of errors of pronouncing silent letters made by English education students at university of Bengkulu the researchers considered that the current research was worth conducting. The question of 
the current research was as followed: What types of pronunciation errors are made by the students of the English education study program when they deal with English silent letters? The researchers expected this research would give the students valuable information and be beneficial for the English lecturers to the success and progress of teaching English silent letters.

\section{Research Methodology}

The research used a descriptive quantitative method. As quoted by Sudjiono in Ayumi (2018), the descriptive quantitative method is a method that described the state of a phenomenon that has been done by the measuring instrument, then processed following the function. The study was conducted at the English Education Study Program at Bengkulu University. The population of the research was the seventh semester students. Arikunto in Salwa (2017) stated that, a population is a set (or collection) of all elements possessing one or more attributes of interest. There were 94 students. They were distributed in 3 classes. Class A consist of 31, class B consist of 34 , and class $C$ consist of 29 . Thus the selected samples were 30 students; 10 students from Class A, 11 students from Class B and 9 students from Class $C$.

Pronunciation test and interview were used as the instrument to find out the types of errors made by the students in pronouncing words that contained the silent letters. Arikunto in Salwa (2017) stated that the device the researchers used to collect data is called an instrument. The words of English silent letters included in the pronunciation test was as followed:

\begin{tabular}{|l|l|}
\hline $\begin{array}{l}\text { Roger bought a knife in Bengkulu } \\
\text { Indah Mall } 2 \text { days ago }\end{array}$ & $\begin{array}{l}\text { For Caroline knowledge is very } \\
\text { important }\end{array}$ \\
\hline $\begin{array}{l}\text { Christopher thought they were } \\
\text { funny }\end{array}$ & $\begin{array}{l}\text { Rachelle taught me how to be a } \\
\text { sniper }\end{array}$ \\
\hline This is actually Harvard health care & Stay within one table length \\
\hline $\begin{array}{l}\text { That dog will gnaw at an old bone } \\
\text { till you throw a steak }\end{array}$ & A new reign has begun \\
\hline $\begin{array}{l}\text { Now the heart of the ceremony is } \\
\text { psalm }\end{array}$ & $\begin{array}{l}\text { I wrote an article about him in the } \\
\text { journal of criminal psychology }\end{array}$ \\
\hline I hope you like salmon & All residents remain calm \\
\hline $\begin{array}{l}\text { It's a long hustle, but it keeps me } \\
\text { real busy }\end{array}$ & $\begin{array}{l}\text { Moisten hands and wrists before } \\
\text { distributing the soap evenly }\end{array}$ \\
\hline We need to clear the aisle & Barbara loves isle Esme \\
\hline
\end{tabular}




\begin{tabular}{|c|c|}
\hline Sometimes people think wrong & $\begin{array}{l}\text { Mom's been a wreck since your visit } \\
\text { this morning }\end{array}$ \\
\hline You're a true autumn & I'm breaking a solemn promise \\
\hline $\begin{array}{l}\text { Victoria bought a comb two days } \\
\text { ago }\end{array}$ & I doubt anyone like cheese \\
\hline At least everyone is honest & $\begin{array}{l}\text { Pataya did not honor him when he } \\
\text { was live }\end{array}$ \\
\hline Africa's veldt makes me blue & Ezekiel is a handsome man \\
\hline Agatha's knee was broken & $\begin{array}{l}\text { Charlotte going to knock on his } \\
\text { door }\end{array}$ \\
\hline $\begin{array}{l}\text { Honey and dough can whiten the } \\
\text { skin }\end{array}$ & $\begin{array}{l}\text { Salvador very thorough. You and I } \\
\text { both know that }\end{array}$ \\
\hline $\begin{array}{l}\text { A month ago you had a personal } \\
\text { wealth of } \$ 250 \text { million }\end{array}$ & Mr. Emmett makes depth 20 meters \\
\hline Sign another one for more money & I want cologne and a wallet \\
\hline My brother died of Pneumonia & $\begin{array}{l}\text { They say the psych profiles of cops } \\
\text { and criminals are pretty much } \\
\text { identical }\end{array}$ \\
\hline $\begin{array}{l}\text { Mama always gave me almond } \\
\text { milk }\end{array}$ & You got my sunscreen and lip balm \\
\hline $\begin{array}{l}\text { Listen carefully to your parents at } \\
\text { home }\end{array}$ & He will whistle my favorite song \\
\hline I'm going to the island this summer & This islet is inhabited by Mr. Kim \\
\hline $\begin{array}{l}\text { Pass me the wrench to open the } \\
\text { plug }\end{array}$ & This is a wrist without a watch \\
\hline $\begin{array}{l}\text { He used to sing this hymn most } \\
\text { sunsets }\end{array}$ & $\begin{array}{l}\text { Write a column about the growth of } \\
\text { south beach }\end{array}$ \\
\hline We are a debt collecting company & You just gotta be subtle \\
\hline $\begin{array}{l}\text { Lee loves watch tv drama title "The } \\
\text { Heir" }\end{array}$ & Rose waited him for an hour \\
\hline $\begin{array}{l}\text { You got to see our Wednesday } \\
\text { parties }\end{array}$ & Rich Brian carried a handkerchief \\
\hline \multicolumn{2}{|c|}{$\begin{array}{l}\text { Meanwhile, in order to know the instrument was valid, an expert } \\
\text { ement was used to measure the validation of the instrument. To collect } \\
\text { ata the research used application Otter voice meeting notes as the } \\
\text { ment. The data collected were analyzed by using the formula: }\end{array}$} \\
\hline
\end{tabular}

Total number of errors

Total percentage $=\longrightarrow \times 100 \%$

Total number of words 
Moreover, to measure the reliability of the data collected, the researchers used inter-rater to conducted the same measurement or observation of the same sample that calculated used used Cohen Kappa principle. Based on Widhiarso' theory in 2005 the measurement of the score used in two categories; score 1 was if the judgment of the analysis is the same as between the researchers and the rater, and score 0 if the judgment of the analysis is different between the researchers and the rater. The value of the Kappa interpreted as follow:

\begin{tabular}{|l|l|}
\hline \multicolumn{1}{|c|}{ Kappa Value } & \multicolumn{1}{c|}{ Strength of Agreement } \\
\hline$<0.20$ & Poor \\
\hline $0.20-0.40$ & Fair \\
\hline $0.41-0.60$ & Moderate \\
\hline $0.61-0.80$ & Good \\
\hline $0.81-1.00$ & Very Good \\
\hline
\end{tabular}

\section{Results and Discussion}

\section{Results}

Based on the data analysis of students' pronunciation, it was determined the number of the students which were classified in the specific number of errors. The result is displayed in Table 2.

\begin{tabular}{|c|c|c|c|}
\hline Samples & Pre-systematic & Systematic & Post-systematic \\
\hline Student 1 & 33 & 19 & - \\
\hline Student 2 & 33 & 19 & - \\
\hline Student 3 & 33 & 19 & - \\
\hline Student 4 & 33 & 19 & - \\
\hline Student 5 & 33 & 19 & - \\
\hline Student 6 & 33 & 19 & - \\
\hline Student 7 & 33 & 19 & - \\
\hline Student 8 & 33 & 19 & - \\
\hline Student 9 & 33 & 19 & - \\
\hline Student 10 & 33 & 19 & - \\
\hline Student 11 & 33 & 19 & - \\
\hline Student 12 & 33 & 19 & - \\
\hline Student 13 & 33 & 19 & - \\
\hline Student 14 & 33 & 19 & - \\
\hline Student 15 & 34 & 18 & - \\
\hline Student 16 & 33 & 19 & \\
\hline Student 17 & 33 & 19 & - \\
\hline Student 18 & 33 & 19 & - \\
\hline
\end{tabular}




\begin{tabular}{|c|c|c|c|}
\hline Student 19 & 33 & 19 & - \\
\hline Student 20 & 33 & 19 & - \\
\hline Student 21 & 33 & 19 & - \\
\hline Student 22 & 33 & 19 & - \\
\hline Student 23 & 33 & 19 & - \\
\hline Student 24 & 33 & 19 & - \\
\hline Student 25 & 33 & 19 & - \\
\hline Student 26 & 33 & 19 & - \\
\hline Student 27 & 33 & 19 & - \\
\hline Student 28 & 33 & 19 & - \\
\hline Student 29 & 33 & 19 & $\mathbf{0}$ \\
\hline Student 30 & 34 & 18 & $\mathbf{5 6 8}$ \\
\hline Total & $\mathbf{9 9 2}$ & were made & - \\
\hline
\end{tabular}

From the data listed in table, the students were made pre-systematic and systematic errors, and the pre-systematic error occurs the most in the words of the English silent letters. There were 992 total pre-systematic errors, and 568 types of systematic errors occurred by the students. It indicated that the highest type of errors was made by the students was pre-systematic errors.

\begin{tabular}{|c|c|c|c|c|c|}
\hline \multirow{2}{*}{$\begin{array}{c}\text { Silent } \\
\text { Letters }\end{array}$} & \multicolumn{3}{|c|}{ Classes } & \multirow{2}{*}{$\begin{array}{c}\text { Number of } \\
\text { errors }\end{array}$} & \multirow{2}{*}{$\begin{array}{c}\text { Total } \\
\text { percentage }\end{array}$} \\
\hline & A & B & C & & \\
\hline $\mathrm{K}$ & 9 & 7 & 14 & 30 & $25 \%$ \\
\hline gh & 24 & 27 & 20 & 71 & $60 \%$ \\
\hline th & 19 & 22 & 22 & 63 & $52 \%$ \\
\hline$G$ & 31 & 34 & 28 & 93 & $77 \%$ \\
\hline $\mathrm{P}$ & 24 & 25 & 17 & 66 & $55 \%$ \\
\hline $\mathrm{L}$ & 16 & 22 & 20 & 58 & $48 \%$ \\
\hline$T$ & 25 & 28 & 21 & 74 & $61 \%$ \\
\hline$S$ & 29 & 33 & 27 & 89 & $74 \%$ \\
\hline$W$ & 26 & 25 & 23 & 74 & $61 \%$ \\
\hline $\mathrm{N}$ & 18 & 18 & 18 & 54 & $45 \%$ \\
\hline$B$ & 32 & 37 & 24 & 93 & $77 \%$ \\
\hline $\mathrm{H}$ & 24 & 19 & 15 & 58 & $48 \%$ \\
\hline $\mathrm{D}$ & 28 & 28 & 18 & 74 & $61 \%$ \\
\hline Total errors & 305 & 325 & 267 & 897 & \\
\hline
\end{tabular}

Based on the data above, the researchers found that the students made 897 errors from 1.560 data, students of class A made 305 errors, students of class B made 325 errors, and 267 errors were made by the students of class C. Also, the pronunciation errors that occurred the most was in the silent letters " $g$ " and "b" with the total number of errors of each letter was 93 and the percentage was $77 \%$. 


\section{Discussion}

This research aimed to find out the types of pronunciation errors are made by the seventh-semester students of the English Education Study Program of the Faculty of Teacher Training and Education at Bengkulu University when they deal with English silent letters. As quoted by Corder in Ellis (1994), the types of errors categorized into three kinds. There are presystematic error, systematic error, and post-systematic error. The presystematic error occurs when the learner cannot explain why a particular form is chosen, the systematic error occurs when the learner cannot correct the error but can explain the rule applied, and the post-systematic error occurs when the learner can explain the correct rule. The results of this research are discussed as follow:

Based on the results of the research, there was a similarity between this research and Utama (2018), the researcher found that the students made two types of errors, there were pre-systematic and systematic, the type of errors that occurred the most was pre-systematic. This result was similar to Utama (2018) in that the students made two types of errors there were pre-systematic and systematic. It proves that the researcher support Utama's research that each of the words of silent letters has distinct characteristics that the students pronounce each word differently based on their phonological knowledge. Also, the phonotactic constraints of the first language as the mother tongue of the students affected the pronunciation errors they were made.

The highest percentage of pronunciation errors were $77 \%$ for the silent letters "g" and "b". Moreover, Alqunayeer (2016) revealed that the highest percentage of all pronunciation was $68 \%$. It showed that the pronunciation errors in Alqunayeer's research were still fewer than this research.

In this research, there were 897 errors from 1.560 data, the students made the highest errors in the silent letters " $g$ " and " $b$ " with the total number of errors 93 the percentage was $77 \%$. This is in line with Salwa (2017) that the

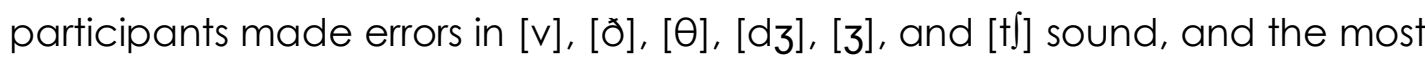
frequent type of interlingual errors of pronunciation made by participants was 
$[\theta]$ sound. There were 178 errors made by the students, with a percentage of 25.95\%. A very significant distinction from previous studies was all the researchers in previous studies revealed the factors that caused the errors.

Contrarily, the results of this research have different from Ayumi (2018). Ayumi's research revealed that the percentage of correct pronunciation from her research was $71.3 \%$ and the incorrect was $28.7 \%$. It indicates that the correct pronunciation was higher than the errors. It is might due to the different subjects involved. This study conducted in English Education Study Program meanwhile, Ayumi's study conducted in non-English Department Students.

From the first problem in this research, this research found that the students of English education study program students occurred errors pronounce pre-systematic and systematic. Many students made errors and can not explain the correct rule of silent letters. It indicates that the students of the English education study program at the University of Bengkulu have problems pronouncing English silent letters. This is in line with Ningrum (2019) and Irianto (2018) who stated that the students of the English Education Study Program at the University of Bengkulu had a lack of ability in recognizing and pronouncing morphophonemic words also not good at pronouncing English consonants in some sounds. The similarity to this research since the studies involved the students from the same study.

Based on the results of the data, the students made two types of pronunciation errors they were pre-systematic and systematic errors. First, Presystematic errors. This type of pronunciation errors occurred when the students were unaware and out of control while pronouncing the words. They tended to ignore the way how to speak by using correct pronunciations so that when they pronounce the words of English silent letters, they were not feeling for incorrect pronunciations made by themselves. As quoted by Corder in Ellis (1994), the pre-systematic error occurs when the learners cannot explain why a particular form is chosen. 
In this type, the researchers found 33 words that were pronounced as pre-systematic errors by students, they were: dough, thorough, gnaw, reign, cologne, psalm, psych, salmon, almond, honest, heir, honor, hustle, moisten, whistle, aisle, isle, islet, veldt, Wednesday, handsome, handkerchief, wrench, wreck, wrist, autumn, hymn, solemn, column, comb, debt, doubt, subtle.

From the data, the researchers stated that there were many words that were errors pronounced by students. When the researchers clarified the students' errors by interviewed them one by one, the fact was they did not realize all the errors. In addition, they were not fully aware to evaluate and correct the pronunciations by themselves.

Secondly, systematic errors. The pronunciation errors occurred to the students who had got the comprehension about the rules of language function; they were errors in practice it. The students fully aware of the rule of phonological symbols in pronunciations, but they could be errors in pronouncing the words. They also could unable to evaluate and correct the errors. According to Corder in Ellis (1994), systematic errors occur when the learners cannot correct the errors but can explain the rules applied.

In this type, the researchers found 19 words that were pronounced as systematic errors by students, they were: know, knife, knee, knowledge, thought, taught, health, wealth, length, depth, sign, pneumonia, psychology, calm, balm, listen, island, wrong, hour.

The example words that were systematic errors made by students. The word was "listen" they often pronounced the word "listen" as /'Izzn/. The proper phonological word should be /'Issn/. Another word was wrong. The word's wrong was pronounced by students as /wro:n/. Even though the correct pronunciation and proper phonological word should be /ro:n/ it sometimes errors caused by the application, Some students pronounced it correctly and knew the rules used, however due to environmental factors such as noise interference, the application recognized wrong pronunciations or did not even detect voice properly. In addition, the utterance must not be repeated because the rules have been made as a sentence can only be 
pronounced once and aloud without repetition. Students needed to open their dictionary or online dictionary to be easier in pronouncing the word correctly.

The data above described that students faced difficulty in pronouncing certain words with the correct pronunciations and proper phonological words. Actually, they had known to pronounce the words well. However, because of their familiarity, they pronounce the words incorrectly. The results showed that students got the comprehension for the rule of language function in pronunciation/ proper phonological, but they were still errors in pronouncing the words. Also, The circumstances factor also affects the pronunciation of students when used the application. This is in line with Utama (2018) that the students made two types of errors were pre-systematic and systematic. Students pronounce each of the words of English silent letters with distinct characteristics differently based on their phonological knowledge. Finally, the students who were categorized into systematic errors had a self-reminder when they made the errors. They tried to correct the errors. This became the type of the third error; it was called post- systematic errors.

This error occurred when the students comprehended the correct pronunciation or proper phonological of target language English, however they used the rules inconsistently for speaking practice. It indicates that they spoke English by using correct pronunciation for some chances, and the other chance they could speak English by using incorrect pronunciation.

The post-systematic errors occurred when the students got the explanation of the rules in pronunciation with the proper phonological. However, they needed a process by stopping for a while to correct the errors. In this case, the students did not make post-systematic errors since the test instructions were not to repeat the pronunciation. The students get the rules of pronunciation when the test has been done. 
From the data above, it could be described that students made two types of errors in pronouncing English silent letters. Also, it could be said that the highest type of errors made by the students was pre-systematic errors.

\section{Conclusion and Suggestion \\ Conclusion}

The researchers would like to draw some conclusions. It was showed that the seventh-semester students of the English education study program at the University of Bengkulu have big problems in pronounced words that contained the silent letters. It could be proved by the research that the English Education Study Program students made two types of errors they were presystematic and systematic errors. The most type of errors that students made was pre-systematic. The researchers also found the highest number of errors made by the students of the English education study program in the pronunciation of the words containing silent letters were " $g$ " and " $b$ " the total number of errors of each letter was 93 and the percentage was $77 \%$.

\section{Suggestion}

After presenting the conclusion, the researchers would like to propose several suggestions for the lecturers of English, the English education study program students, and other researchers.

To all of the English lecturers, especially who teach English Phonetics and Phonology and Speaking courses, they should pay more attention to the students' pronunciation about silent letters, especially in letters "k, gh, th, g, p, $l, t, s, w, n, b, h, d "$. Hopes, there are no more errors occur, such as in pronounce words "know" /nəv/ as /knəv/, "dough" /dəv/ as/dəf/, "hour" /'aver/ as /haver/. Also, they should find a more suitable method or technique for teaching the English silent letters.

To the English Education students, they should eliminate their errors and realize that their pronunciation will influence their future students' pronunciation. They will be their students' role model in pronouncing English silent letters correctly. 
Lastly, the other researchers, they could focus on some experimental or action research to overcome students' errors when they deal with silent letters. They were recommended continuing this research by investigating the English students' problems of English silent letters with bigger samples and also investigate the factors that caused them.

\section{References}

Alqunayeer, H. S. (2016). Pronunciation errors of letter " $G$ " in English language made by Saudi undergraduate students. English language and literature studies Canadian center of science and education. Vol. 6, No. 4.

Arikunto, S. (1998). Prosuder penelitian suatu pendekatan praktek. Jakarta: PT. Rineka Cipta.

Ayumi, P. (2018). The pronunciation of English words containing silent letter " $G$ " by the elementary and advanced level students of English made easy (EME) English course. Undergraduate Thesis. Yogyakarta: Universitas Sanata Dharma.

Brown, H. D. (2000). Teaching by principles 2nd ed. Now York: Pearson Education Longman Group.

Brown, H. D. (2007). Teaching by principles: an interactive approach to language pedagogy. New York: Pearson Education, Inc.

Ellis, R. (1994). The study of second language acquisition (Oxford Applied Linguistics). Philadelphia: Oxford University Press.

Gilakjani, A. P. (2012). "A match or mismatch between learning styles of the learners and teaching styles of the teachers". Modern Education and Computer Science. 11:51-60.

Irianto, N, A., Imranudin, \& Sabarudin, S. (2018). An analysis of pronunciation errors of English consonants : $/ \theta /$ and $/ \circlearrowright /$ by the students of the English education study program of University of Bengkulu. Journal of English Education and Teaching (JEET), 2(3).

Kenworthy, J. (1987). Teaching English pronunciation. New York: Longman Inc.

Ningrum, S. C. (2019). An analysis of students' ability in pronouncing morphophonemic in English words. Undergraduate Thesis. Bengkulu: Universitas Bengkulu. 
Pallawa, B, A. (2013). A comparative analysis between English and Indonesian phonological system. International Journal of English Language Education. 1(3), 103-129.

Podhaizer, M. (2001). Painless spelling. New York: Baron's Educational Series.

Salwa, S. (2017). An Analysis of interlingual errors in English pronunciation made by the fifth semester students of English education study program At Uin Raden Fatah Palembang. Undergraduate thesis. Islamic State Palembang: University Raden Fatah.

Styvant, R., Arasuli., \& Afriazi, R. (2019). An analysis of English speaking syllable words stress errors by the students of English education study program of University of Bengkulu. Journal of English Education and Teaching. 3(1), 106-115.

Taylor, J. R. (1997). An introduction to error analysis (2nd ed). California: University Science Books.

Utama, T. T. (2018). Error analysis of silent letters "H" and "W" in English words by non-English department students". Undergraduate Thesis. Yogyakarta: Sanata Dharma University

Widhiarso, W. (2005). Mengestimasi realiabilitas. Yogyakarta: Fakultas Psikologi UGM. 